\title{
Patent Ductus Arteriosus in Adults: Surgical Experience in Ivory-Coast
}

\author{
${ }^{1}$ H. Yangni-Angate, ${ }^{1}$ G. Ayegnon, ${ }^{1}$ C. Meneas, ${ }^{1}$ F. L. Diby and ${ }^{2}$ Y. Yapobi \\ ${ }^{1}$ Department of Thoracic and Cardiovascular Surgery, Bouake Teaching Hospital and Institute of Cardiology, \\ and ${ }^{2}$ Department of Anaesthesia and Intensive Care, Institute of Cardiology, Abidjan, Ivory-Coast \\ Reprint requests to: Hervé Yangni-Angate, O1bp5119, Abidjan01, Cote D'Ivoire \\ E-mail:yangniangate@yahoo.fr
}

\begin{abstract}
Background: Patent ductus arteriosus surgery is well documented. Hospital Mortality has reduced to almost $0 \%$. Yet, with adults, this surgical cure is likely to be difficult and require some technical skills Method: A retrospective study of surgical procedures and results after surgery of patent ductus arteriosus (PDA) in adults.

Results: Since 1978 to 2000 we have reported 16 operated cases. The average age was 22.5 years. There was female predominance with a sex ratio of 2.3/1. All patent ductus arteriosus had been confirmed by two dimensional echocardiography (2D echocardiography) and cardiac catheterization. All hemodynamic types of Nadas classification were observed. Double or triple ligation supported on Teflon felt was the most frequent technique used (69\%). This technique gave good results in view of the absence of hospital mortality and only 1 case of recanalisation after a long follow up of all patients from $1-7$ years (mean 5 years).
\end{abstract}

Conclusion: Double or triple ligation on Teflon felt according to Wright technique is a good technique.

Key words: Puctus ductus arteriosus, adult, surgery

\begin{abstract}
Résumé
Introduction : La chirurgie persistance du canal artériel est bien codifiée. Mortalité hospitalière devient plus inférieure ou presque $0 \%$. Néanmoins, chez des adultes, ce remède chirurgicale parait être difficile et demande quelque connaissance technique.

Méthode : Le but de cette étude rétrospective est d'analyser notre attitude chirurgicale et nos résultats au cours de la chirurgie de la persistance du canal artériel (PCA) chez l'adulte.

Résultats : De 1978 à 2000, nous avons colligé 16 cas opérés. L'âge moyen étaitt de 22.5 ans. Il y a une prédominance féminine avec un sex ratio de 1.6/1. Chez tous les patients, la PCA a été confirmée par l'échocardiographie bidimensionnelle et le cathétérisme cardiaque droit. Tous les types hémodynamiques de la classification de Nadas étaient retrouvées. La double ou triple ligature appuyée sur bandelette de Téflon a été le procédé technique le plus souvent exécuté (69\% des cas). Cette méthode chirurgicale ne nous a apporté des résultats satisfaisants avec une mortalité opératoire nulle, 1 cas de reperméabilisation immédiate corrigée avec succès et une absence de reperméabilisation du canal artériel à long terme après un suivi moyen de 5 ans (extrêmes 1 à 7 ans) de tous nos patients.
\end{abstract}

Conclusion: Au vu de notre expérience, la double ou triple ligature sur bandelette de Téflon selon Wright peut s'envisager efficacement dans la cure chirurgicale de la PCA de l'adulte.

Mots clés : persistance canal artériel, adulte, chirurgie

\section{Introduction}

Nowadays, patent ductus arteriosus (PDA) surgery is well documented. ${ }^{1-3}$ Hospital mortality is almost approaching zero. ${ }^{4,5}$ Yet, with adults, this surgical cure is likely to be difficult and require some technical skills; ${ }^{5-7}$ particularly, when dealing with calcified, atheromatic or weakened ducts because of strong pulmonary or systemic arterial high blood pressures. ${ }^{8,9}$ This is a report of the experience using ligation on Teflon strip (Wright technique) ${ }^{10}$ in adults in Ivory-Coast.

\section{Material and Methods}

From 1977 to 2000, 16 adults were operated upon for PDA at Bouake Teaching Hospital and Institute of Cardiology, Abidjan, Ivory-Coast. There were 10 females and 6 males aged $18-40$ years 
(mean 22.5 years). Fourteen patients had functional signs of left-right shunt (Table 1) and all the patients had continuous cardiac murmur under the left clavicle.

Chest radiograph showed cardiomegally in 10 patients (mean cardiothoracic ratio 0.53). All patients had evidence of pulmonary hypervascularisation on chest radiographs and 7 had distension of the pulmonary artery. Electrocardiogram (ECG) showed left ventricular hypertrophy in 10 patients. ECG and right cardiac catheterization confirmed diagnosis in all patients. The pulmonary pressures were $15 \mathrm{mmHg}$ $80 \mathrm{mmHg}$ (mean $27 \mathrm{mmHg}$ ). The mean pulmonary pressure was high at $30 \mathrm{mmHg}$ in 4 patients. According to Nadas hemodynamic classification, ${ }^{6} 5$ patients had type I disease, 7 type IIa and 4 type IIb.

The surgical approach was left lower lateral thoracotomy at the level of $4^{\text {th }}$ intercostal space. The surgical procedure consisted of; double or triple ligation of the PDA on Teflon strip (11 patients); suture ligation of the PDA (5 patients). A temporary operating clamping test of the ductus arteriosus was carried out in one patient; this patient had a bidirectional shunt with left predominance and mean systemic pulmonary pressure of $80 \mathrm{mmHg}$. Good tolerance of the clamping allowed triple ligation on Teflon strip to proceed.

\section{Results}

\section{Immediate}

There was no hospital mortality. Post operative course was uneventful in all 16 patients.

\section{Late}

Every patient was reexamined and follow up was 1 7 years. Recanalisation was noticed in one patient who had triple ligation on Teflon strip; subsequent suture ligation was successful.

Table 1: Clinical features in 16 adults with patent ductus arteriosus

\begin{tabular}{ll}
\hline Feature & $\begin{array}{l}\text { No. } \\
(\mathrm{n}=16)\end{array}$ \\
\hline Dyspnoea & 12 \\
Recurrent respiratory tract infection & 5 \\
Tachypnoea & 2 \\
Unexpected discovery & 2 \\
\hline
\end{tabular}

\section{Discussion}

The double or triple ligation on Teflon strip as described by Wright ${ }^{10}$ is our first surgical option for the treatment of PDA in adults. The technique is less expensive, achievable, less traumatizing, and is quicker to perform. It is efficient and carries no hospital mortality. The utility and effectiveness of this procedure has been demonstrated in a series of 145 children with PDA in Ivory-Coast.

Suture ligation ${ }^{2}$ is another technique carried out with close-heart surgery. It was used on 5 patients in the present report. In adults, using suture ligation requires particular caution as the PDA is sometimes fragile at this age. ${ }^{3,7}$ This fragility is so acute that there is a high pulmonary or systemic arterial blood pressure. ${ }^{7}$ Furthermore, it may become necessary to resort to a cardio-pulmonary bypass when haemostasis becomes difficult to achieve. For these reasons, suture ligation is not our first surgical option. We prefer to use this technique when there is no high systemic arterial blood pressures and /or when there are normal or moderately high pulmonary pressures.

Techniques requiring the use of cardio-pulmonary bypass are expensive and not always suitable in our setting.

Ligation on Teflon strip can be safely used for treatment of PDA in adults. This method is so useful that it can be applicable in every surgical centre in Africa where open-heart surgeries are not carried out.

\section{References}

1. Goor AD, Lillehei WC. Patent ductus arteiosus. In: Congenital malformations of the heart. Grune and Straton, New York, 1975; 340 - 351

2. Kirkun JW, Barrat-Boyes BG. Patent ductus arteriosus. In: Cardiac surgery. Churchill Livingstone, New York, 1993; 841 - 859

3. Rampha LPS, Irvine R, Spencer HW. Surgery for patent ductus arteriosus still the gold standard. West Indian Med J 2000; 4: 294 - 297

4. Zhonghua WZZ. Long-term results of surgical treatment of patent ductus arteriosus in adults. Chinese Journal of Surgery 1993; 31: 431 - 432

5. Aghaji MAC, Ojimba TA. Review of 322 cases of ductal surgery in Enugu. Tropical Cardiology 1993; 19: 113 - 116

6. Guilmet D, Soyer R, Brunet A, Gandjbakhch J, Dubost $\mathrm{CH}$. Cure Chirurgicale du canal arteriel avec hypertension pulmonaire par voie endoaortique sous assistance circulatoire. Cœur $1971 ; 2: 389-398$

7. John S, Murcidharam S, Jairaj PS, et al. The adult ductus: review of surgical experience with 131 patients. J Thorac Cardiovasc Surg 1981; 82: 314 $-319$

8. Pavie A, Msika S, Mussat T, et al. Traitement chirurgical du canal artériel de l'adulte. Arch Mal Coeur $1983 ; 12$ : 1431-1436

9. Cellemajer DS, Sholler GF, Hughes CF, Baird DK. Persistent ductus arteriosus in adults. A review of surgical experience with 25 patients. Med J Aust 1991; 4: 233 - 236

10. Wright JS, Newman DC. Ligation of the patent ductus. J Thorac Cardiovasc Surg 1978; 75: 695 698 